\title{
School Flexible Learning Spaces, Student Movement Behaviour and Educational Outcomes among Adolescents: A Mixed-Methods Systematic Review
}

\begin{abstract}
BACKGROUND: To achieve sustainable, scalable improvements in student movement behaviour in the classroom setting, educational priorities must be considered. Flexible learning spaces that employ student-centred pedagogy and contain a range of furniture and layout options, implemented to improve educational outcomes, may enable additional unintended health benefits. The purpose of this review was to summarize the evidence on the effects of flexible learning spaces on adolescent student movement behaviours and educational outcomes.
\end{abstract}

METHODS: Five databases were searched, with five quantitative and one qualitative article meeting the review criteria.

RESULTS: Findings showed that students in flexible learning spaces spent significantly less time sitting, and more time standing and moving. Students were also more engaged, on-task, and collaborated and interacted more. Academic results for English, Mathematics and Humanities for those in flexible learning spaces were also higher, compared to peers in traditional classrooms.

CONCLUSION: The preliminary evidence from the reviewed studies suggests that there may be beneficial outcomes across some movement behaviours as well as learning 
outcomes in classrooms that employ student-centred pedagogy and utilize a built environment that facilitates autonomy and choice around where and how to learn. These learning environments present an opportunity for an interdisciplinary approach to address sedentary behaviour in the classroom setting.

KEYWORDS: Learning environment, sedentary behaviour, movement, engagement, collaboration, interdisciplinarity.

The foundations for many health behaviours are laid during childhood, track through adolescence and are largely established by adulthood, making this early period one of the most critical in terms of developing a healthy body and mind ${ }^{1}$. Given the considerable amount of time students spend at school, there is broad agreement that educational institutions are not only responsible for offering quality learning opportunities, but also for creating environments that strengthen the physical, social and emotional development of students. This is evidenced by the World Health Organization's Health Promoting Schools Framework ${ }^{2}$ which proposes a holistic, ecologically grounded approach to creating school environments that facilitate health behaviours and foster health and wellbeing. It is further echoed by efforts from education departments to develop frameworks that addressing student wellbeing at school ${ }^{3}$. From a curricular perspective physical education and health topics are routinely taught, affording students the opportunity for structured physical activity $^{4}$ and to learn about physical, mental and social health, ultimately for public health benefit.

\section{Classroom-based Sedentary Behaviour}


A persistent issue of concern, with implications for both health and educational outcomes, is the high rate of classroom-based sedentary time. The longest bouts of uninterrupted child and adolescent sitting occur on weekdays during school hours, when students are largely confined to classrooms ${ }^{5}$. By the middle years of secondary school, students sit for $70 \%$ of the school day ${ }^{6}$. Research indicates that young people who spend prolonged periods of time sitting have poorer physical profiles across a range of cardiometabolic indicators ${ }^{7,8}$. Greater time spent sedentary has also been associated with depression in adolescent girls ${ }^{9}$ and a reduced ability to control attention and on-task behaviour among early adolescents ${ }^{10}$.

Despite concerted efforts to increase physical activity in the school setting, systematic reviews of interventions focused on health education have shown that these have been largely ineffective $\mathrm{e}^{11}$. Behaviour change interventions that seek to reduce sedentary time, such as incorporating stand-biased desks into classrooms, show promising result, but are likely to encounter challenges in terms of scalability ${ }^{12}$. Alternatively, 'activity break' interventions aimed at increasing movement and stimulating cognitive processes, are proving to be effective in achieving positive results in both domains ${ }^{13}$. The challenge here lies in the reliance on the motivation, skills and time of individual teachers, which collectively have the potential to threaten scalability and long-term sustainability of such initiatives.

The question "what types of interventions to reduce sedentary behaviour are feasible from a public health standpoint? " first raised by $\operatorname{Katzmarzyk}^{14}$, is as relevant today as it 
was 10 years ago. An additional question is what types of public health interventions are feasible from an educational standpoint? To answer this, interdisciplinary systems approaches grounded in collaborative priority setting and decision making with key stakeholders - taking into account differing needs, views and expertise - are required ${ }^{15}$.

\section{1st Century Learning Environments}

Education systems globally are undergoing a paradigm shift in pedagogical approach to better meet student learning needs ${ }^{16,17}$. As educators adapt their educational practices and move towards a student-centred approach, the standard classroom layout typified by rows of desks and chairs no longer lends itself to the educational practices taking place ${ }^{18}$. As a result, classrooms are being modified to contain a wide selection of furniture in a relatively open space, which can be configured to facilitate a variety of pedagogical approaches and learning experiences, whilst utilizing a range of technologies ${ }^{19}$. These spaces are referred to by several names including flexible learning spaces (FLS), next-generation learning environments (NGLE), 21st century learning environments or innovative learning environments (ILE). The characteristic they share is flexibility in both form and function, from a physical and pedagogical perspective ${ }^{20}$.

Research into the link between the indoor school environment, pedagogical approaches, sedentary behaviour and physical activity, and how these factors and behaviours may influence each other is emerging ${ }^{21}$. It has been reported that the interplay between the physical and pedagogical elements, coupled with the teacher's ability to capitalise on the affordances of the space, are key enablers of effective learning in flexible 
learning spaces ${ }^{18}$. Taking an interdisciplinary approach and examining the learning environment holistically from a physical, pedagogical and social perspective is therefore essential, to gain an understanding of the complexity of the interaction among these various elements and the effect they have on both movement behaviours (sitting, standing, stepping) and educational outcomes, is essential.

The purpose of this review was to systematically examine the body of evidence on school flexible learning spaces (termed as such from here on for ease of reporting), and student movement behaviour and educational outcomes among adolescents. The aim was to look broadly across outcomes of interest from both a public health and educational perspective, in an attempt to collate evidence to inform efforts addressing sedentary behaviour in the classroom setting.

\section{METHODS}

This systematic review was registered with the International Prospective Register of Systematic Reviews (PROSPERO) (Record \# CRD42018109103) and has followed the Preferred Reporting Items for Systematic Reviews and Meta-Analyses (PRISMA) guidelines for reporting systematic reviews. A mixed-methods systematic review was deemed appropriate to investigate this topic as the context is under-researched and not well understood $^{22,23}$. The benefit of a mixed-methods review is that it combines the power of stories and numbers, with the strengths of both methods compensating for their respective limitations ${ }^{24}$.

\section{Inclusion and Exclusion Criteria}


Studies were included if they (1) involved healthy, typically developing school students with a mean age of 12-17 years at baseline, conducted in upper primary, middle, junior or secondary school (2) investigated both the built classroom environment (furniture/layout) and pedagogical approaches (such as student-centred, project/problembased learning) and (3) reported on at least one movement behaviour or educational outcome. Qualitative, quantitative and mixed methods studies were included and there was no criteria placed on the research design. Studies investigating clinical populations (such as youth living with overweight/obesity or a disability) or students experiencing learning difficulties were excluded.

Consistent with our definition that a flexible learning space encompasses both the built environment and the teaching approach, the following criteria were applied. The built classroom environment was defined as an indoor teaching space, typically featuring a polycentric layout, with a variety of moveable furniture allowing flexible layout possibilities, with or without mention of elements such as air quality, temperature, light and noise. In terms of pedagogical approach, included studies made mention of their specific teaching approaches (e.g student-centred, project/problem-based learning, or personalised learning) with or without reference to the incorporation of information and communications technology (ICT).

\section{Search Strategy}

Five electronic databases (Scopus, ProQuest, Education Research Complete, PubMed and Web of Science) were searched up until November 2019. (See Supplementary 
Materials for search strategy). No date limits were applied. Reference lists of included studies and relevant reviews ${ }^{21-23}$ were also searched for further publications. All searches were exported into Endnote and duplicates were removed. Titles and abstracts were independently screened by KK and YE and irrelevant articles removed. Full-text versions of selected articles were then obtained and inclusion and exclusion criteria applied independently by KK and YE. Any discrepancies were discussed and resolved.

\section{Data Extraction}

The following information was extracted from the selected studies: (a) author, year of publication, country, (b) study design, (c) participant characteristics, (d) aim of the study, (e) condition, (f) exposure, (g) method of assessment, (h) movement behaviour measures, (i) learning behaviour/academic measures, (j) movement behaviour outcomes, (k) learning behaviour/academic outcomes. Relevant data were extracted by KK and verified by YE.

Discrepancies were resolved through a consensus discussion.

\section{Risk of Bias (Quality) Assessment}

A risk of bias/quality assessment was carried out on each included article, using a modified tool developed for assessing mixed-method reviews ${ }^{25}$. Quantitative experimental studies were assessed according to the study design, randomization, blinding and complete outcome data. Assessment of observational studies was based on sampling appropriateness, justification of measures used and the control of confounding variables. Qualitative studies were assessed according to the study's objective, appropriateness of design or method, description of context, description of participants and sampling justification, data collection 
and analysis and discussion of researchers' reflexivity. Information on the risk of bias for individual studies was extracted, scored by KK and reviewed by YE, with any discrepancies in scoring resolved through discussion.

\section{Synthesis}

Given the small number of included studies and the heterogeneity of study aims, research designs, methods, outcomes measured and units of analysis, a narrative synthesis of all significant reported outcomes was completed.

\section{RESULTS}

Six papers describing five different studies met the inclusion criteria - stating changes to both the built environment and pedagogical approach as opposed to one or the other (See Figure 1). All were published in the last six years and all but one was conducted in Australia. Five of the studies ${ }^{26-30}$ were quantitative and one ${ }^{18}$ used qualitative methods. A detailed description of the key characteristics of the six studies included in this review is presented in Table 1. Overall, there were more commonalities among the traditional classrooms and among flexible learning spaces across the studies, than differences. The key features of traditional classrooms were front-facing seating arrangements and a teachercentred, didactic approach, whilst flexible learning spaces were characterised by a variety of furniture, group tables and collaborative, student-centred pedagogy.

All five quantitative studies employed a crossover trial/single subject research design, comparing the same students across multiple learning environments. Four studies ${ }^{26,27,29,30}$ compared students across two conditions. One was a flexible learning space, characterised 
by a polycentric layout with a range of furniture options facilitating a variety of studentcentred learning modes. The other was a traditional classroom, typified by front-facing rows of tables and chairs predominantly used for teacher-led, didactic instruction. One study ${ }^{28}$ compared students across three different learning environments. A traditional classroom (as described above), a space with grouped tables lending itself to group and collaborative work, and the third a flexible learning space (as described above). The two studies by Byers et al, ${ }^{26,27}$ and the study by Imms \& Byers ${ }^{28}$ were experimental and conducted in the same school, while the two studies by Kariippanon et al, ${ }^{29,30}$ were observational and conducted in the same nine schools.

The two studies by Kariippanon et al, ${ }^{29,30}$ were cross-sectional with students spending a double period lesson $($ mean time $=80 \mathrm{~min})$ in the flexible learning spaces. The remaining three studies by Byers ${ }^{26,27}$ and Imms \& Byers ${ }^{28}$ were prospective. Exposure time ranged from one school term (9-10 weeks) in the flexible learning space ${ }^{28}$, to three terms in the flexible learning space ${ }^{26}$, to one school year in the flexible learning space ${ }^{27}$. Two studies ${ }^{29,30}$ utilised a within-group comparison while the three experimental prospective studies ${ }^{26-28}$ conducted both a within-group analysis and a cross-sectional between-group analysis. The qualitative study ${ }^{18}$ was conducted in eight schools (four primary and four secondary) among students who regularly used the flexible learning spaces within their schools.

Overall, one study ${ }^{30}$ reported only movement behaviour outcomes, four studies reported only educational outcomes ${ }^{26-29}$, and one study ${ }^{18}$ presented movement behaviour, wellbeing and educational outcomes. 


\section{Risk of Bias (Quality) Assessment}

All three experimental studies ${ }^{26-28}$ were of moderate quality. Students in these studies were not randomized or blinded to the conditions. However given the context this is difficult to achieve. These studies used both a single subject research design and a casecontrol design. The studies had complete outcome data and were prospective. Both observational studies ${ }^{29,30}$ had a moderate quality rating. Though cross-sectional, they used appropriate sampling, validated, objective instruments and were able to control for major confounding variables through keeping the students, teacher and subject constant across conditions. The qualitative study ${ }^{18}$ was rated as high quality across all indicators other than researcher reflexivity (See Table 2).

\section{Studies Investigating Movement Behaviour Outcomes}

Two studies ${ }^{30,18}$ investigated movement behaviour outcomes. See Table 3 for the measures used and the reported outcomes.

Sedentary behaviour. One study ${ }^{30}$ objectively measured sedentary behaviour (total time, bouts and breaks) and total standing and stepping time using thigh-mounted inclinometers, over a double period lesson (mean wear time $=80 \mathrm{~min})$ among 191 students. Students in flexible learning spaces spent significantly less time sitting, and more time standing and stepping/moving compared to traditional classrooms, all with large effects. Further, a significant decrease in prolonged bouts $(>30 \mathrm{~min})$ per hour of class time, an increase in intermittent bouts ( $\leq 9 \mathrm{~min})$ and an increase in breaks in sitting were reported, compared to students in traditional classrooms, all with small to moderate effects. 
In the qualitative study ${ }^{18}$ with 85 participants, students spoke about the increased freedom and opportunities to break up sitting and move around the flexible learning space. They described the autonomy to work in different postures as enhancing their wellbeing.

Comfort. Students in the qualitative study ${ }^{18}$ self-reported that the level of comfort associated with different furniture items ranged from very comfortable to uncomfortable. Students stated that higher levels of comfort were enabled by elements such as cushioned seats, couches, beanbags and pillows. Discomfort was predominantly reported to be in relation to a lack of back support when sitting on ottomans or leaning forward over a low tables to work. Discomfort in the flexible spaces was partially mitigated by the ability to move around and not be confined to the furniture.

\section{Studies Investigating Educational Outcomes}

Four quantitative ${ }^{26-29}$ and one qualitative ${ }^{18}$ study, examined the effect of flexible learning spaces compared to traditional classrooms on learning behaviours. In each of these studies the same students were assessed in both traditional and flexible conditions. The three prospective studies ${ }^{26-28}$ relied on student self-report, while the cross-sectional study ${ }^{29}$ utilised classroom observations.

Three studies ${ }^{26-28}$ additionally examined the effect of these different learning environment types on academic outcomes. This was achieved by comparing standardized test results of students who had participated in the studies, to test results of like-ability matched peers in a traditional classroom. See Table 4 for the measures used and the reported outcomes. 
Learning behaviours. The learning behaviours that were reported in these studies ${ }^{26-}$ 29,18 covered the following constructs: student-centric modalities, autonomy, behavioural engagement, cognitive engagement and interaction.

Student-centric modalities. In three studies ${ }^{27-29}$ students self-reported on the types of learning modalities that occurred in flexible learning spaces. In the two prospective studies $^{27-28}$ with 385 and 52 students respectively, students self-reported a significant increase in active, collaborative, creative and personalised learning when in the flexible learning space condition.

In another study ${ }^{29}$ the 60 students observed cross-sectionally spent significantly less class time being taught in a whole class setting, engaged in teacher-led instruction and working individually in flexible learning spaces. Further, students were observed spending significantly more time in group settings and collaborating in the flexible learning spaces than in traditional classrooms.

Autonomy. Students in the qualitative $\operatorname{study}{ }^{18}$ reported experiencing higher levels of autonomy in relation to how and where to learn in the flexible learning spaces.

Behavioural engagement. Five studies ${ }^{26-29,18}$ reported significantly greater behavioural engagement in the flexible learning space compared to students in traditional classrooms. In one study ${ }^{28}$ engagement was defined as students' positive attitude, willingness to take on a challenge, master new skills, innovative problem solving and motivation to gain good grades. In this study ${ }^{28}$ across three conditions, in which students spent one school term, significant increases were observed in both the group work focused space and the flexible 
learning space, compared to the traditional classroom, with a direct correlation between student engagement and time spent in the space. An increasingly negative effect on students' willingness to take on a challenge was observed in the traditional classroom. In two other studies ${ }^{26,27}$ behavioural engagement related to students' level of interest, engagement and enjoyment in the classroom space. Based on these constructs the flexible learning spaces was the rated the preferred learning environment and students reported a significant increase in engagement after having spent between three school terms ${ }^{26}$ to one school year ${ }^{27}$ in the flexible learning space, both with large effects.

In the two studies by Kariippanon and colleagues ${ }^{29,18}$ behavioural engagement was defined as time spent on-task and engaged in the lesson content. A significant increase in active on-task behaviour and a significant decrease in verbally off-task behaviour was observed, compared to the traditional classroom, with small effects. In the qualitative study ${ }^{18}$ students indicated they felt more engaged with the lessons in the flexible learning space.

Cognitive engagement. One study ${ }^{27}$ examined cognitive and emotional engagement, defined as interest in learning, among students across different learning environments. Students self-reported that their cognitive and emotional engagement was highest in the flexible learning space compared to the traditional classroom.

Interaction. Two studies ${ }^{28-29}$ found that students experienced increased interaction with their peers in the flexible learning space. In one study ${ }^{28}$ students also reported a positive effect on the student-teacher relationship in the flexible learning space. 
Academic outcomes. The three prospective studies ${ }^{26-28}$ reported a significant association between flexible learning space and improvements in academic results, with moderate effects. One study ${ }^{26}$ examined standardized English results and reported that five out of six classes in the flexible learning space showed significant improvements in English scores. Significant improvements were also found in Mathematics scores in four out of six classes, pre to post the intervention. For both subjects effect sizes ranged from the upper end of small to large. Between-group cross-sectional analysis revealed significant, stable improvements across English and Mathematic scores between one- two thirds of a grade among students in flexible learning spaces.

A second study ${ }^{27}$ measured the impact of the transition of students from 6 classes from a traditional classroom to a flexible learning space on academic performance in English, Humanities and Mathematics. Effect sizes showed that for all classes, academic results improved with the greatest gains observed in Mathematics. Hierarchical Linear Modelling (HLM) was conducted to evaluate the impact of the different layouts on student academic outcomes. Seven out of the nine HLMs indicated that the various classroom spaces did account for a significant effect on student grades. The statistically significant variances in student grades ranged from $2 \%$ to $11 \%$.

A third study ${ }^{28}$ compared Mathematics scores between three classes of 52 students that had spent a school term each in three classroom types (traditional, group work enabling, flexible) to three classes of like-ability peers in a traditional classroom. It was reported that 
students in all three modes of learning spaces significantly outperformed their peers in the traditional condition, with medium to very large effects.

\section{DISCUSSION}

By applying a holistic definition to what constitutes a flexible learning space, incorporating both the built environment and pedagogical approach, and examining educational and movement behaviour outcomes among students learning in these spaces, we were able to provide useful insights into the effects of these innovative new learning environments. Given that only six studies met the selection criteria, confirms that this field is considerably under-researched. Only one stuy ${ }^{18}$ examined the effects of flexible learning spaces on movement behaviour and learning behaviour outcomes, while two studies conducted among the same cohort of students investigated differences in sedentary behaviour $^{30}$ and learning behaviours ${ }^{29}$. The remaining three studies ${ }^{26-28}$ were carried out in the same school and only examined learning behaviours and academic outcomes, in alignment with educational research and school priorities.

From a movement behaviour perspective, one study provided evidence that students moved around flexible learning spaces more frequently compared to traditional classrooms which resulted in significant reductions in total sedentary time and increases in standing and stepping during the lesson. In terms of learning behaviours, three studies collectively reported an increase in student-centric modalities, exemplified by a greater proportion of class time spent working collaboratively in groups, less teacher-led instruction and a more personalised, creative and active learning experience in flexible learning spaces. 
Considerable improvements in behavioural and cognitive engagement were also reported in one study, along with more positive student-student interactions in two studies. In three studies, academic outcomes across English, Mathematics and Humanities were significantly stronger among students who had spent between one school-term up to one school year in a flexible learning space, compared to like-ability peers in a traditional classrooms. In summary, these preliminary findings across all outcomes were generally positive however, given that the evidence base is in its infancy, they must be interpreted with caution.

To our knowledge this is the first systematic review to have investigated the effects of flexible learning spaces, taking into account flexibility in both form (physical) and function (pedagogical), and examined the effect of these spaces on both movement behaviours and educational outcomes. There have been two main reviews conducted that have examined the relationship between the built learning environment and learning outcomes ${ }^{22,23}$. In their literature review Blackmore and colleagues (2011) focused equally on what was missing from the research as they did synthesizing evidence to support connections between learning spaces and student outcomes. They found that few studies showed any direct causal link between new and improved learning spaces and positive achievement in standardized tests. Further, they noted that the literature linking learning spaces to student behaviour and learning focused on measures of building conditions and was very generalized. This was also noted by Ucci and colleagues (2015) in their scoping review of indoor school environments, physical activity, sitting behaviour and pedagogy, who found 
that the majority of the literature examining this issue was published in journals concerned with the built environment rather than education. A more recent systematic review by Byers and colleagues (2017) also examined the effects of learning environments on student learning outcomes. They noted the considerable inconsistency in the design of learning space evaluations. In both the Blackmore (2011) and Byers (2017) reviews the focus was more on establishing a relationship between the built environment and learning outcomes without specifically looking at the role of pedagogy and how the space is used. Both noted the lack of rigorous, empirical evaluations on the impact of flexible learning spaces on adolescent outcomes.

Historically teaching approaches have necessitated high levels of sedentary behaviour during class time and the layout of classrooms was designed to suit direct transmission of information, with the teacher situated at the front. This significantly restricted the ability of students to take an active role in their learning ${ }^{31,32}$ or to move around the spaces and collaborate. The affordances of flexible learning spaces coupled with the student-centred teaching approach described in the studies include in this review, gave students the autonomy to choose where and how to work in the space. Students consequently took the opportunity to sit less and move more during class time and to collaborate and interact with other students as they went about their learning tasks. Students reported a more positive learning experience with higher levels of behavioural and cognitive engagement that appears to have translated into improved academic outcomes. 
Comparative analysis between survey responses capturing student views of flexible learning spaces and test results measuring academic achievement, revealed that the most statistically significant effects (improvements in academic achievement) occurred in classes where teachers capitalized on the affordances of the flexible learning space for pedagogical gain $^{27}$. This was reiterated by Imms \& Byers ${ }^{28}$ who found that across both high-ability and mixed-ability classes, students who had spent a school term each in three different types of learning environments (including a traditional classroom) consistently outperformed their like-ability peers in Mathematics from a traditional classroom. The difference observed between the traditional mode and the traditional control classroom suggests an effect of the teacher, their approach and relationships with students as influencing academic outcomes. This confirms that the potential gains from these spaces lie in both their form and function or how learning spaces are designed and how they are used.

\section{Strengths and Limitations}

A strength of this review is that it sought to move beyond looking at the public health gains that can be obtained from flexible learning spaces, by incorporating the effect these learning environments have on educational outcomes. This is essential due to the limited success associated with scaling and sustaining interventions that predominantly focus on reducing sedentary behaviour or increasing physical activity in the classroom setting and schools more broadly. We cannot continue to work across siloed systems and structures, formulate policy, design and implement interventions and hope to achieve progress. Then find ourselves perplexed when our well-intentioned efforts fall short of achieving 
anticipated outcomes. These silos all too frequently function in isolation from one another, restrict interactions and the cross-pollination of ideas and knowledge, thereby limiting what can be achieved.

By acknowledging that the core business of schools is to enhance educational outcomes for students, with health and wellbeing secondary to this, an agenda for joint research and practice priorities can be set. By demonstrating that what is beneficial for educational outcomes may also benefit students' movement behaviours and wellbeing, is a partial answer to the question what public health interventions are feasible from an educational standpoint? It moves beyond the imposition of 'interventions' on already stretched educators, to working together for mutually beneficial gain.

A limitation of this review is that the included studies were all pilot in nature, with small sample sizes, conducted across a very small number of schools. Though demonstrating significance and with sizeable effects suggesting a positive trend, the results must be interpreted with caution as the strength of the evidence is very weak. A challenge to summarizing the findings collectively is the range of methodological approaches, the different definitions of constructs being investigated and the widely diverse units of analysis that were present across the studies. A further potential limitation is the definition of flexible learning spaces use in this review. By requiring 'flexibility' to refer to both the built environment and the pedagogical approach, the number of included studies was significantly reduced. 
The need for consistent methodologies for investigating the effects of flexible learning spaces so as to build a reliable evidence base is apparent. Although group RCTs might be the gold standard to demonstrate effects, these might not be feasible so more pragmatic designs including step-wedge and natural experiments (with comparison groups) may be needed. Larger (many schools) and longer studies are needed to more clearly understand potential flexible learning space effects and account for possible factors that might influence the effects (for example teacher effects, differences in flexible learning space design etc).

Based on these findings we reiterate the call for interdisciplinary, inter-sectoral systems approaches, grounded in collaborative priority setting and decision making with key stakeholders. This notion is promoted in research, policy and practice, yet it is not executed comprehensively or effectively on a consistent basis. A 2014 review on the Health Promoting School framework for improving the health and well-being of students and their academic achievement, found few studies included any academic, attendance or schoolrelated outcomes; stating that no clear conclusions could be drawn as to the effectiveness of the health promoting schools framework for improving academic achievement ${ }^{33}$. Barriers may include a lack of appreciation of the value of an interdisciplinary approach, funding constraints imposed by discipline-specific grant schemes, or the time or capacity to expand the scope of research beyond traditional disciplinary boundaries. The responsibility to address these barriers rests equally with academics, policy makers and practitioners. 
Research into the effects of health and wellbeing on educational outcomes has shown mixed results but overall suggest a significant positive association between general health status and learning outcomes ${ }^{34,35}$. Ideally, improvements in one area support and facilitate advances in the other. Research More specifically evidence suggests a positive association between movement during class time and learning outcomes ${ }^{36}$. Further research is needed to examine the relationship between sedentary behaviour and academic performance, which may have important implications for both public health and education systems ${ }^{37}$.

\section{Conclusion}

Our findings indicate that there is limited available evidence on the effects of flexible learning spaces on movement behaviour and educational outcomes. It can be tentatively suggested that the implementation of flexible learning spaces has the potential to result in a "win-win" situation where schools obtain the improved educational outcomes they are seeking and as an unintended consequence there are potential public health benefits to be gained from interrupting prolonged sitting.

\section{IMPLICATIONS FOR SCHOOL HEALTH}

This systematic review has highlighted that research into flexible learning spaces, whilst in its infancy, shows promising results for health, wellbeing and educational outcomes. Research into the effects of flexible learning spaces has identified that schools can make considerable contributions to reducing sedentary time during lessons and improving academic outcomes by: 
- Adapting the built classroom environment to include portable tables, writable walls and a polycentric layout

- Adapting teaching approached to be student-centred, giving students greater choice and autonomy in where and how to learn in the classroom

- Offering teachers professional development on the design and pedagogical approaches used in flexible learning spaces, with strategies on how to capitalise on the affordances of these spaces for student movement, wellbeing and learning.

The following recommendations ensure that a robust evidence base is built so that potential student health and educational benefits of flexible learning spaces are maximized:

- An interdisciplinary research agenda that looks holistically at the interactions between the built environment and the pedagogical approach in these innovative environments.

- Experimental or longitudinal study designs that generate quality evidence to better understand the effects of flexible learning spaces.

- Consultation and decision making around the furnishing of flexible learning spaces underpinned by research evidence that goes beyond the educational implications and considers student movement and wellbeing.

\section{HUMAN SUBJECTS APPROVAL STATEMENT}

Preparation of this paper did not require original data collection with human subjects.

\section{CONFLICT OF INTEREST DISCLOSURE STATEMENT}

All authors of this article declare they have no conflicts of interest. 


\section{REFERENCES}

1. Craigie AM, Lake AA, Kelly SA, Adamson AJ, Mathers JC. Tracking of obesityrelated behaviours from childhood to adulthood: A systematic review. Maturitas. 2011;70(3):266-284.

2. World Health Organization. Health Promoting Schools. 1998. Division of Health Promotion, Education and Communication - Health Education and Health Promotion Unit. Geneva, Switzerland.

3. NSW Department of Education. The Wellbeing Framework for Schools. 2015 https://www.det.nsw.edu.au/wellbeing/about/16531_Wellbeing-Framework-forschools_Acessible.pdf. Accessed October 9, 2019

4. Sallis JF, McKenzie TL, Beets MW, Beighle A, Erwin H, Lee S. Physical education's role in public health: Steps forward and backward over 20 years and HOPE for the future. Res $Q$ Exerc Sport. 2012;83(2):125-135.

5. Harrington DM, Dowd KP, Bourke AK, Donnelly AE. Cross-Sectional analysis of levels and patterns of objectively measured sedentary time in adolescent females. Int J Behav Nutr Phys Act. 2011;8:1-7.

6. Carson V, Ridgers ND, Howard BJ, et al. Light-Intensity Physical Activity and Cardiometabolic Biomarkers in US Adolescents. PLoS One. 2013;8(8):1-7.

7. Carson V, Hunter S, Kuzik N, et al. Systematic review of sedentary behaviour and health indicators in school-aged children and youth: an update. Appl Physiol Nutr Metab Appl Physiol Nutr Metab Downloaded from. 2016;41(June):240-265. 
8. Tremblay MS, LeBlanc AG, Kho ME, et al. Systematic review of sedentary behaviour and health indicators in school-aged children and youth. Int J Behav Nutr Phys Act. 2011;8(1):98:1-22.

9. Suchert V, Hanewinkel R, Isensee B, et al. Sedentary behavior, depressed affect, and indicators of mental well-being in adolescence: Does the screen only matter for girls? J Adolesc. 2015;42:50-58.

10. Niet V Der, Anneke G, Erik JA. Associations between daily physical activity and executive functioning in primary school-aged children. J Sci Med Sport. 2015;18:673-677.

11. Metcalf B, Henley W, Wilkin T. Effectiveness of intervention on physical activity of children: Systematic review and meta-analysis of controlled trials with objectively measured outcomes (EarlyBird 54). BMJ. 2012;345(7876):1-11.

12. Rossi T, Pavey A, Macdonald D, McCuaig L. Teachers as health workers: Patterns and imperatives of Australian teachers' work. Br Educ Res J. 2016;42(2):258-276.

13. Barr-anderson DJ, Auyoung M, Whitt-glover MC, Glenn BA, Yancey AK. Integration of short bouts of physical activity into organizational routine: A systematic review of the literature. Am J Prev Med. 2011;40(1):76-93.

14. Katzmarzyk PT. Physical activity, sedentary behavior, and health: Paradigm paralysis or paradigm shift? Diabetes. 2010;59(11):2717-2725.

15. Morton KL, Atkin AJ, Corder K, Suhrcke M, Turner D, Van Sluijs EMF. Engaging stakeholders and target groups in prioritising a public health intervention: The 
Creating Active School Environments (CASE) online Delphi study. BMJ Open. 2017;7(1):1-12.

16. Jonassen, D., \& Land S. Theoretical Foundations of Learning Environments. 2nd ed. Abingdon: Routledge.; 2012.

17. Prain, V., Cox, P., Deed, C., Edwards, D., Farrelly, C., Keeffe M et al. Characterising personalised learning. In: V. Prain, ed. Personalising Learning in Open-Plan Schools. ; 2015. SensePublishers, Rotterdam.

18. Kariippanon KE, Cliff DP, Lancaster SL, Okely AD, Parrish AM. Perceived interplay between flexible learning spaces and teaching, learning and student wellbeing. Learn Environ Res. 2017:1-20.

19. NSW Department of Education. First look at NSW classrooms of the future. Press Release. https://www.nsw.gov.au/news-and-events/news/future-classroomsunveiled/. Published 2015.

20. Fisher K. The Translational Design of Schools: An Evidence-Based Approach to Aligning Pedagogy and Learning Environments. Sense Publishing, Rotterdam; 2016.

21. Ucci M, Law S, Andrews R, et al. Indoor school environments, physical activity, sitting behaviour and pedagogy: A scoping review. Build Res Inf. 2015;43(5):566581.

22. Blackmore J, Bateman D, Loughlin J, O’Mara J, Aranda G. Research into the Connection between Built Learning Spaces and Student Outcomes.; 2011. https://www.education.vic.gov.au/Documents/about/programs/infrastructure/blackm 
orelearningspaces.pdf. Accessed October 242019.

23. Byers T, Mahat M, Liu K, Knock A, Imms W. Systematic Review of the Effects of Learning Environments on Student Learning Outcomes. 2018. http://www.iletc.com.au/publications/reports. Accessed October 122019.

24. Pluye P, Nha Hong Q. Combining the Power of Stories and the Power of Numbers: Mixed Methods Research and Mixed Studies Reviews. Annu. Rev. Public Health. 2014.35:29-45.

25. Pluye P, Gagnon MP, Griffiths F, Johnson-Lafleur J. A scoring system for appraising mixed methods research, and concomitantly appraising qualitative, quantitative and mixed methods primary studies in Mixed Studies Reviews. Int J Nurs Stud. 2009;46(4):529-546.

26. Byers T, Imms W, Hartnell-Young E. Making the Case for Space: The Effect of Learning Spaces on Teaching and Learning. Curric Teach. 2014;29(1):5-19.

27. Byers T, Imms W, Hartnell-Young E. Comparative analysis of the impact of traditional versus innovative learning environment on student attitudes and learning outcomes. Stud Educ Eval. 2018;58(July):167-177.

28. Imms W, Byers T. Impact of classroom design on teacher pedagogy and student engagement and performance in mathematics. Learn Environ Res. 2017;20(1):139152.

29. Kariippanon KE, Cliff DP, Lancaster SJ, Okely AD, Parrish AM. Flexible learning spaces facilitate interaction, collaboration and behavioural engagement in secondary 
school. PLoS One. 2019;14(10):1-13

30. Kariippanon KE, Cliff DP, Okely AD, Parrish AM. Flexible learning spaces reduce sedentary time in adolescents. J Sci Med Sport. 2019;22(8):918-923.

31. McGregor J. Space and schools. Forum Fam Plan West Hemisph. 2004;46(1).

32. Upitis R. School Architecture and Complexity. Complicity An Int J Complex Educ. 2004;1(1):19-38.

33. Langford R, Bonell CP, Jones HE, Pouliou T, Murphy SM, Waters E, et al. The WHO Health Promoting School framework for improving the health and well-being of students and their academic achievement. Cochrane Database Syst Rev. 2014;4(CD008958):1-249

34. Fransoo R, Roos N, Martens P, Heaman M, Levin B, Chateau D. How health status affects progress and performance in school: A population-based study. Can J Public Heal. 2008;99(4):344-349.

35. Murray SD, Hurley J, Ahmed SR. Supporting the Whole Child Through Coordinated Policies, Processes, and Practices. J Sch Health. 2015;85(11):795-801.

36. Donnelly JE, Lambourne K. Classroom-based physical activity, cognition, and academic achievement. Prev Med (Baltim). 2011;52(SUPPL.):S36-S42.

37. Voss MW, Carr LJ, Clark R, Weng T. Revenge of the "sit" II: Does lifestyle impact neuronal and cognitive health through distinct mechanisms associated with sedentary behavior and physical activity? Ment Health Phys Act. 2014;7(1):9-24. 


\section{Figure 1. Flowchart of Study Selection Process}

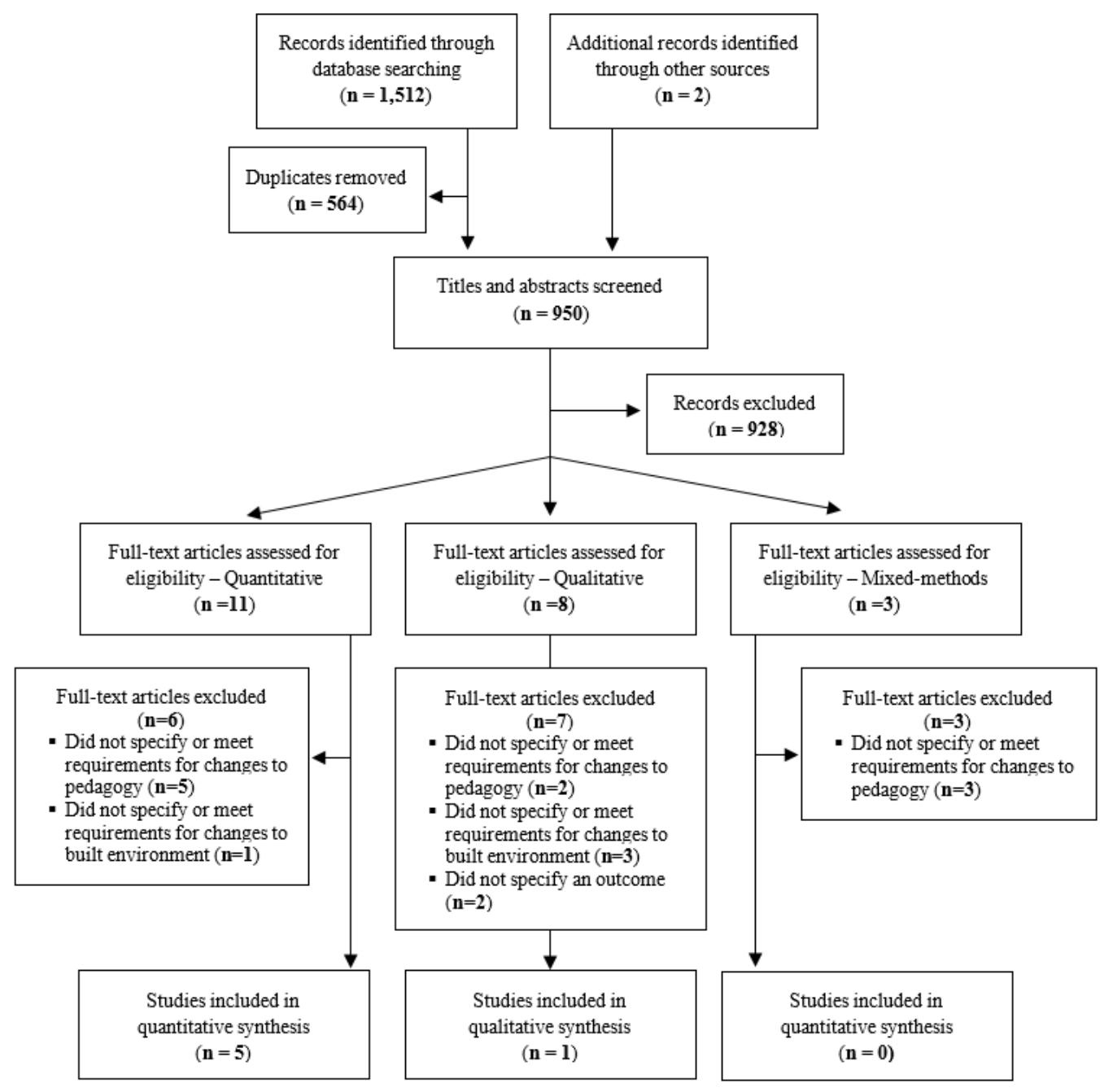


Table 1. Summary of Characteristics of Studies Included in this Review

\begin{tabular}{|c|c|c|c|c|c|c|}
\hline $\begin{array}{l}\text { Author, date, } \\
\text { country }\end{array}$ & $\begin{array}{l}\text { Study } \\
\text { design }\end{array}$ & $\begin{array}{l}\text { Participant } \\
\text { characteristics }\end{array}$ & Study aim & Condition & Exposure & Method of assessment \\
\hline \multicolumn{7}{|c|}{ Quantitative studies } \\
\hline $\begin{array}{l}\text { Byers et al., } \\
\text { 2014; Australia } \\
\text { (26) }\end{array}$ & $\begin{array}{l}\text { Quasi- } \\
\text { experimental } \\
\text { SSRD; Case- } \\
\text { control }\end{array}$ & $\begin{array}{l}\mathrm{N}=164 ;(6 \text { classes in } \\
\text { intervention); } \mathrm{n}=16 \\
\text { control); Grade } 7-8 ; \\
\text { Age } 11-14 ; 100 \% \text { male }\end{array}$ & $\begin{array}{l}\text { To examine the impact of learning spaces } \\
\text { on students' learning experience, in-class } \\
\text { engagement and learning outcomes in a } \\
\text { technology-rich school setting - new- } \\
\text { generation learning environment (NGLS). }\end{array}$ & $\begin{array}{l}\text { TC condition: chairs set in rows, front facing, teacher-centred, didactic } \\
\text { instructional approach. } \\
\text { NGLS condition: stools, booths, ottomans, portable tables, chairs, writable } \\
\text { walls, polycentric layout, integration of digital and visual technologies, } \\
\text { enabling } 3 \text { learning modes - teacher-centred, student-centred and informal } \\
\text { learning. }\end{array}$ & $\begin{array}{l}1 \text { school terms spent in the TC } \\
\text { condition, followed by } \\
3 \text { terms spent in the NGLS } \\
\text { condition. }\end{array}$ & $\begin{array}{l}\text { Student Attitudinal Survey (repeated } \\
\text { measure); } \\
\text { Academic Assessment Services } \\
\text { (ASS) testing instrument }\end{array}$ \\
\hline $\begin{array}{l}\text { Byers et al., } \\
2018 \text { Australia } \\
\text { (27) }\end{array}$ & $\begin{array}{l}\text { Quasi- } \\
\text { experimental } \\
\text { SSRD; Case- } \\
\text { control }\end{array}$ & $\begin{array}{l}\mathrm{N}=385 ; 22 \text { Classes; } \\
\text { Grade } 7 \text { to } 9 ; \text { Age } 11- \\
15 ; 100 \% \text { male }\end{array}$ & $\begin{array}{l}\text { To compare students' attitudes to their } \\
\text { learning experiences, motivation, } \\
\text { engagement and academic outcomes in a } \\
\text { traditional classroom (TC) \& innovative } \\
\text { learning environment (ILE) over a school } \\
\text { year. }\end{array}$ & $\begin{array}{l}\text { TC condition: reflected a conventional design with desks and chairs } \\
\text { arranged in fixed rows or small groups emphasized a teacher-centred } \\
\text { didactic approach. } \\
\text { ILE condition: utilised a combination of spatial (furniture, whiteboards) and } \\
\text { digital technologies, polycentric layout to support teachers to influence and } \\
\text { mould the space to their pedagogical intent. }\end{array}$ & $\begin{array}{l}\text { II group spent half a school year in } \\
\text { each classroom type } \\
\text { IC group spent one school year in } \\
\text { the ILE } \\
\text { TC group spent one school year in } \\
\text { the TC. }\end{array}$ & $\begin{array}{l}\text { Linking Pedagogy, Technology, and } \\
\text { Space (LPTS) Survey; Motivated } \\
\text { Strategies for Learning } \\
\text { Questionnaire (MSLQ); } \\
\text { Student attitudinal survey; } \\
\text { Student academic achievement; }\end{array}$ \\
\hline $\begin{array}{l}\text { Imms \& Byers; } \\
2017 ; \\
\text { Australia (28) }\end{array}$ & $\begin{array}{l}\text { Quasi- } \\
\text { experimental } \\
\text { SSRD; Case- } \\
\text { control }\end{array}$ & $\begin{array}{l}\mathrm{N}=52 ; \\
3 \text { Classes; } \\
\text { Grade 7; Age not } \\
\text { specified; } 100 \% \text { male }\end{array}$ & $\begin{array}{l}\text { To evaluate how teachers use open, } \\
\text { flexible, one-on-one technology learning } \\
\text { spaces and the effect on student } \\
\text { engagement and learning outcomes in } \\
\text { Mathematics, compared to traditional } \\
\text { classrooms. }\end{array}$ & $\begin{array}{l}\text { Mode 1: 'front-of-class' orientation, rows of desk to suit teacher-centred } \\
\text { didactic instruction, limited opportunities for student interaction and group- } \\
\text { focused activities. } \\
\text { Mode 2: Student-centred space, clustered table arrangement to facilitate } \\
\text { group work, informal interactions with teacher and students. } \\
\text { Mode 3: polycentric layout, multiple whiteboards, TVs on wheels, a variety } \\
\text { of non-traditional, dynamic and interactive space. }\end{array}$ & $\begin{array}{l}\text { Classes spent one school term in } \\
\text { each Mode. }\end{array}$ & $\begin{array}{l}\text { Linking Pedagogy, Technology, and } \\
\text { Space (LPTS); } \\
\text { Academic Assessment Services } \\
\text { (ASS) testing instrument }\end{array}$ \\
\hline $\begin{array}{l}\text { Kariippanon et } \\
\text { al., } 2019 \\
\text { Australia (29) }\end{array}$ & $\begin{array}{l}\text { School based } \\
\text { cross-over } \\
\text { trial }\end{array}$ & $\begin{array}{l}\mathrm{N}=60 ; 9 \text { Classes; } \\
\text { Grade } 7 \text { to } 9 ; \text { mean age } \\
13.2 ; \mathrm{M}: \mathrm{F} 55: 45\end{array}$ & $\begin{array}{l}\text { To compare student learning behaviours } \\
\text { between traditional classrooms (TC) and } \\
\text { flexible learning spaces (FLS). }\end{array}$ & $\begin{array}{l}\text { TC condition: chairs set in rows, teaching from front of classroom, teacher- } \\
\text { centred, individual tasks. } \\
\text { FLS condition: grouped tables, standing workstations, ottomans, couches, } \\
\text { write-able tables/walls, lacking a distinct front of classroom, student-centred, } \\
\text { self-directed, group-work focused. }\end{array}$ & $\begin{array}{l}\text { One double-period lesson }(\mathrm{mean}= \\
\text { 80min) in a traditional classroom } \\
\text { One double-period lesson (mean = } \\
\text { 80min) in a FLS. }\end{array}$ & \begin{tabular}{|l|} 
Classroom observation \\
\end{tabular} \\
\hline $\begin{array}{l}\text { Kariippanon et } \\
\text { al., } 2019 \\
\text { Australia (30) }\end{array}$ & $\begin{array}{l}\text { School based } \\
\text { cross-over } \\
\text { trial }\end{array}$ & $\begin{array}{l}\mathrm{N}=191 ; 9 \text { Classes; } \\
\text { Grade } 7 \text { to 9; mean age } \\
13.2 ; \text { M:F 50:50 }\end{array}$ & $\begin{array}{l}\text { To compare student sitting patterns } \\
\text { between traditional classrooms (TC) and } \\
\text { flexible learning spaces (FLS). }\end{array}$ & $\begin{array}{l}\text { TC condition: chairs set in rows, teaching from front of classroom, teacher- } \\
\text { centred, individual tasks. } \\
\text { FLS condition: grouped tables, standing workstations, ottomans, couches, } \\
\text { write-able tables/walls, lacking a distinct front of classroom, student-centred, } \\
\text { self-directed, group-work focused. }\end{array}$ & $\begin{array}{l}\text { One double-period lesson (mean = } \\
\text { 80min) in a traditional classroom } \\
\text { One double-period lesson (mean = } \\
\text { 80min) in a flexible learning space. }\end{array}$ & Accelerometry (activPAL) \\
\hline \multicolumn{7}{|c|}{ Qualitative studies } \\
\hline $\begin{array}{l}\text { Kariippanon et } \\
\text { al., 2017; } \\
\text { Australia (18) }\end{array}$ & $\begin{array}{l}\text { Cross- } \\
\text { sectional case } \\
\text { study }\end{array}$ & $\begin{array}{l}\mathrm{N}=85 ; \text { Grade 5-10; } \\
\text { Age 10-17; M:F 53:47 }\end{array}$ & $\begin{array}{l}\text { To explores the perceived relationship } \\
\text { between flexible learning spaces (FLS) and } \\
\text { teaching, learning and wellbeing outcomes. }\end{array}$ & $\begin{array}{l}\text { FLS condition: grouped tables, standing workstations, ottomans, couches, } \\
\text { write-able tables/walls, lacking a distinct front of classroom; student- } \\
\text { centred, self-directed, group-work focused. }\end{array}$ & $\begin{array}{l}\text { Students had spent time in both } \\
\text { their schools traditional classrooms } \\
\text { and flexible learning spaces. }\end{array}$ & \begin{tabular}{|l|} 
Interviews; \\
Focus-groups
\end{tabular} \\
\hline
\end{tabular}


Table 2. Risk of Bias (Quality) Assessment

\begin{tabular}{|c|c|c|c|c|c|c|c|}
\hline \multicolumn{8}{|c|}{ Quantitative - Experimental } \\
\hline & Prospective & $\begin{array}{l}\text { Allocation } \\
\text { concealment } \\
\text { and/or } \\
\text { blinding }\end{array}$ & $\begin{array}{l}\text { Complete } \\
\text { outcome } \\
\text { data and/or } \\
\text { low } \\
\text { withdrawal } \\
\end{array}$ & $\begin{array}{l}\text { Appropriate } \\
\text { sequence } \\
\text { generation } \\
\text { and/or } \\
\text { randomization } \\
\end{array}$ & & & Score \\
\hline Byers et al. ${ }^{26}$ & 1 & 0 & 1 & 1 & & & 75 \\
\hline Byers et al. ${ }^{27}$ & 1 & 0 & 1 & 1 & & & 75 \\
\hline Byers \& Imms ${ }^{28}$ & 1 & 0 & 1 & 1 & & & 75 \\
\hline \multicolumn{8}{|c|}{ Quantitative - Observational } \\
\hline & $\begin{array}{l}\text { Appropriate } \\
\text { sampling } \\
\text { and sample }\end{array}$ & $\begin{array}{l}\text { Justification of } \\
\text { measurements } \\
\text { (validity and } \\
\text { standards) }\end{array}$ & $\begin{array}{l}\text { Control of } \\
\text { confounding } \\
\text { variable }\end{array}$ & Prospective & & & \\
\hline Kariippanon et al. ${ }^{29}$ & 1 & 1 & 1 & 0 & & & 75 \\
\hline Kariippanon et al. ${ }^{30}$ & 1 & 1 & 1 & 0 & & & 75 \\
\hline \multicolumn{8}{|l|}{ Qualitative } \\
\hline & $\begin{array}{l}\text { Qualitative } \\
\text { objective or } \\
\text { question }\end{array}$ & $\begin{array}{l}\text { Appropriate } \\
\text { approach, } \\
\text { design or } \\
\text { method } \\
\end{array}$ & $\begin{array}{l}\text { Description } \\
\text { of the } \\
\text { context }\end{array}$ & $\begin{array}{l}\text { Description of } \\
\text { participants \& } \\
\text { justification of } \\
\text { sampling }\end{array}$ & $\begin{array}{l}\text { Description of } \\
\text { qualitative } \\
\text { data collection } \\
\text { and analysis } \\
\end{array}$ & $\begin{array}{l}\text { Discussion of } \\
\text { researchers' } \\
\text { reflexivity }\end{array}$ & \\
\hline Kariippanon et al. ${ }^{18}$ & 1 & 1 & 1 & 1 & 1 & 0 & 85 \\
\hline
\end{tabular}


Table 3. Summary of Movement Behaviours and Outcomes

\begin{tabular}{|c|c|c|}
\hline Author, date, country & $\begin{array}{l}\text { Movement behaviour } \\
\text { measures }\end{array}$ & Movement behaviour outcomes \\
\hline \multicolumn{3}{|l|}{ Quantitative Studies } \\
\hline $\begin{array}{l}\text { Kariippanon et al., } \\
2019 ; \\
\text { Australia }^{30}\end{array}$ & $\begin{array}{l}\text { Total sedentary time, } \\
\text { bouts of sitting, } \\
\text { breaks in sitting; } \\
\text { total standing time; } \\
\text { total stepping time }\end{array}$ & $\begin{array}{l}\text { Significant differences compared to control. } \\
18 \% \text { less sitting }(\mathrm{d}=-1.47, \mathrm{p}=.001) \\
15 \% \text { more standing }(\mathrm{d}=1.37, \mathrm{p}=.001) \\
3 \% \text { more stepping }(\mathrm{d}=.99, \mathrm{p}=.001) \\
2.20 \text { more bouts }(<9 \mathrm{~min}) \text { of sitting per hour }(\mathrm{d}=.32, \mathrm{p}=.002) \\
-0.02 \text { less bouts }(>30 \text { min }) \text { of sitting per hour }(\mathrm{d}=-.65, \mathrm{p}=.001) \\
2.13 \text { more breaks in sitting per hour }(\mathrm{d}=.26, \mathrm{p}=.003)\end{array}$ \\
\hline \multicolumn{3}{|l|}{ Qualitative Studies } \\
\hline $\begin{array}{l}\text { Kariippanon et al., } \\
2018 ; \\
\text { Australia }^{18}\end{array}$ & $\begin{array}{l}\text { Sedentary time; } \\
\text { Movement; } \\
\text { Comfort }\end{array}$ & $\begin{array}{l}\text { Compared to TC condition students reported increased opportunity and freedom to } \\
\text { break up sitting and move around the space; furniture ranged from very comfortable } \\
\text { to uncomfortable. }\end{array}$ \\
\hline
\end{tabular}


Table 4. Summary of Educational Measures and Outcomes

\begin{tabular}{|c|c|c|}
\hline $\begin{array}{l}\text { Author, date, } \\
\text { country }\end{array}$ & Educational measures & Educational outcomes \\
\hline \multicolumn{3}{|c|}{ Quantitative Studies } \\
\hline $\begin{array}{l}\text { Byers et al., } \\
2014 ; \\
\text { Australia }^{26}\end{array}$ & $\begin{array}{l}\text { a) Learning experience (active, creative, } \\
\text { collaborative, personalised); } \\
\text { b) Engagement (interest/enjoyment); } \\
\text { c) Standardized English \& Mathematics results } \\
\text { (pre/post in NGLE ) } \\
\text { d) Comparison of English \& Mathematics results in } \\
\text { NGLE to standardized academic ability in TC }\end{array}$ & $\begin{array}{l}\text { Significant positive shift across classes compared to controls. } \\
\text { a) Student learning experiences }(\mathrm{d}=1.01-2.01) \\
\text { b) Student engagement }(\mathrm{d}=1.16-2.48) \\
\text { Significant improvements from pre/post in NGLE } \\
\text { a) } 5 / 6 \text { English classes }(\mathrm{d}=.32-.55) \\
\quad 4 / 6 \text { Mathematics classes }(\mathrm{d}=.32-.68) \\
\text { Significant improvement in composite scores (between-group) } \\
\text { b) English classes - (Composite }=+.01-+.03) \\
\text { Mathematics classes - (Composite }=-.23-+.14)\end{array}$ \\
\hline $\begin{array}{l}\text { Byers et al., } \\
2018 ; \\
\text { Australia }^{27}\end{array}$ & $\begin{array}{l}\text { a) Learning experience (active, creative, } \\
\text { collaborative, personalised); } \\
\text { b) Cognitive and emotional engagement; } \\
\text { c) Academic performance in English, Humanities } \\
\text { and Mathematics }\end{array}$ & $\begin{array}{l}\text { Significant differences (within-group - pre/post). } \\
\text { a) } 5 / 6 \text { classes }(p=0.008-0.001) \\
\text { b) } 5 / 6 \text { classes }(p=<0.001-0.002) \\
\text { c) English }(g=0.26-0.56) \text {; Humanities }(g=0.11-0.51) \text {; Maths }(g=0.40 \text { - } \\
1.19) \\
\text { Significant differences (between-group - intervention/control). } \\
\text { a) } 5 / 6 \text { classes }(p=<0.001-0.002) \\
\text { b) } 6 / 6 \text { classes }(p=<0.001) \\
\text { c) } 2-11 \% \text { academic variance }(p=<0.05)\end{array}$ \\
\hline $\begin{array}{l}\text { Imms \& } \\
\text { Byers; 2016; } \\
\text { Australia }^{28}\end{array}$ & $\begin{array}{l}\text { a) Student engagement (positive attitude, } \\
\text { willingness to take on a challenge) } \\
\text { b) Standardized mathematics scores }\end{array}$ & 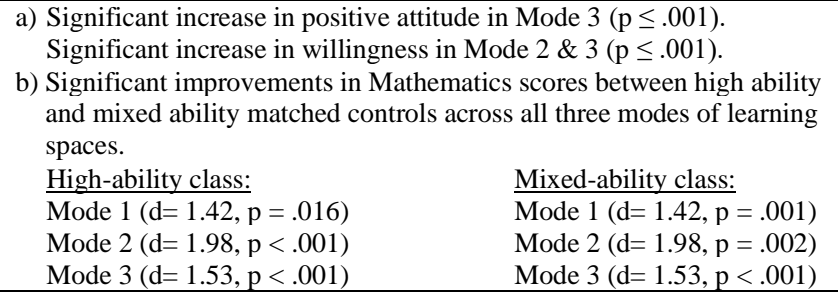 \\
\hline $\begin{array}{l}\text { Kariippanon } \\
\text { et al., 2019; } \\
\text { Australia }^{29}\end{array}$ & $\begin{array}{l}\text { a) Student physical setting; } \\
\text { b) Mode of learning; } \\
\text { c) Behavioural engagement (time-on-task); } \\
\text { d) Interaction (teacher/peers); } \\
\text { e) Technology use }\end{array}$ & $\begin{array}{l}\text { Significant difference compared to control: } \\
\text { a) Large group }(>6) \text { settings }(\mathrm{d}=.61, \mathrm{p}=.001) \\
\text { Whole class setting }(\mathrm{d}=-0.65, \mathrm{p}=.001) \\
\text { Working individually }(\mathrm{d}=-0.79, \mathrm{p}=.001) \\
\text { b) Collaboration }(\mathrm{d}=1.33, \mathrm{p}=.001) \\
\text { Engagement in teacher-led instruction }(\mathrm{d}=-.75, \mathrm{p}=.001) \\
\text { c) Active engagement }(\mathrm{d}=.50, \mathrm{p}=.001) \\
\text { Verbally off-task }(\mathrm{d}=-.44, \mathrm{p}=.016) \\
\text { d) Positive peer to peer interaction }(\mathrm{d}=.88, \mathrm{p}=.001) \\
\text { e) Technology use }(\mathrm{d}=-.26, \mathrm{p}=.022)\end{array}$ \\
\hline \multicolumn{3}{|c|}{ Qualitative Studies } \\
\hline $\begin{array}{l}\text { Kariippanon } \\
\text { et al., 2018; } \\
\text { Australia }^{18} \\
\end{array}$ & $\begin{array}{l}\text { Autonomy; engagement; interaction; } \\
\text { collaboration; }\end{array}$ & $\begin{array}{l}\text { Compared to TC condition students in FLS reported enhanced autonomy, } \\
\text { engagement, interaction, and collaboration. }\end{array}$ \\
\hline
\end{tabular}

